\title{
Change-makers bring on recombinant antibodies
}

There's a growing affinity for recombinant antibodies. Some say it's also high time for animal-free recombinants.

\author{
Vivien Marx
}

t's a lush experience to peruse antibody catalogs, with their estimated two to three million reagents. Around 8,500 of them are specific to the epidermal growth factor receptor (EGFR). Joy awaits researchers who find a promising binder for 'their' protein. In this antibody bounty, change-makers see limitations and relics of an outdated era. Change is needed because labs no longer wish to be stung by the discovery that catalog antibodies work in a published paper but fail on their bench ${ }^{1-4}$. Chasing down the reason - is the failure due to the antibody, the application or the latest El Niño oscillation? - means too much chasing down rabbit holes. Speaking of rabbits, scientists can and should abandon the use of animal-derived antibodies, says a recent European Commission (EC) report ${ }^{5}$.

In regard to animal-free antibodies, "that's not a bad idea at all and I think we're getting closer to that," says Peter McPherson, a neuroscientist McGill University's Montreal Neurological Institute-Hospital who was not involved with the report. Recombinant antibodies have entered the scene, and offerings are growing. "The beauty of recombinants is, of course, that they're consistent through time," he says. And they're renewable. Recombinants can be animal-derived and non-animal-derived. McPherson has a favorite presentation slide sequence compiled by his postdoctoral fellow Carl Laflamme with micrographs from 15 published papers with 3,500 first-layer citations and 66,000 secondary citations. C9ORF72, a protein implicated in amyotrophic lateral sclerosis and frontotemporal dementia, is localized to different spots in the cell: the nucleus, the Golgi, endosomes, lysosomes, actin and cytosol. "By the time you're done the whole cell is full of green," says McPherson. Almost all the papers involve work with an antibody that did not recognize C9ORF72. That's upsetting, he says, given how much labs want to know whether and how protein expression connects to these diseases. To help avoid such issues, McPherson, along with Aled Edwards of the University of Toronto, is spearheading a new large-scale antibody characterization effort. It might make comparing antibodies, both recombinant and traditional, more transparent. It might

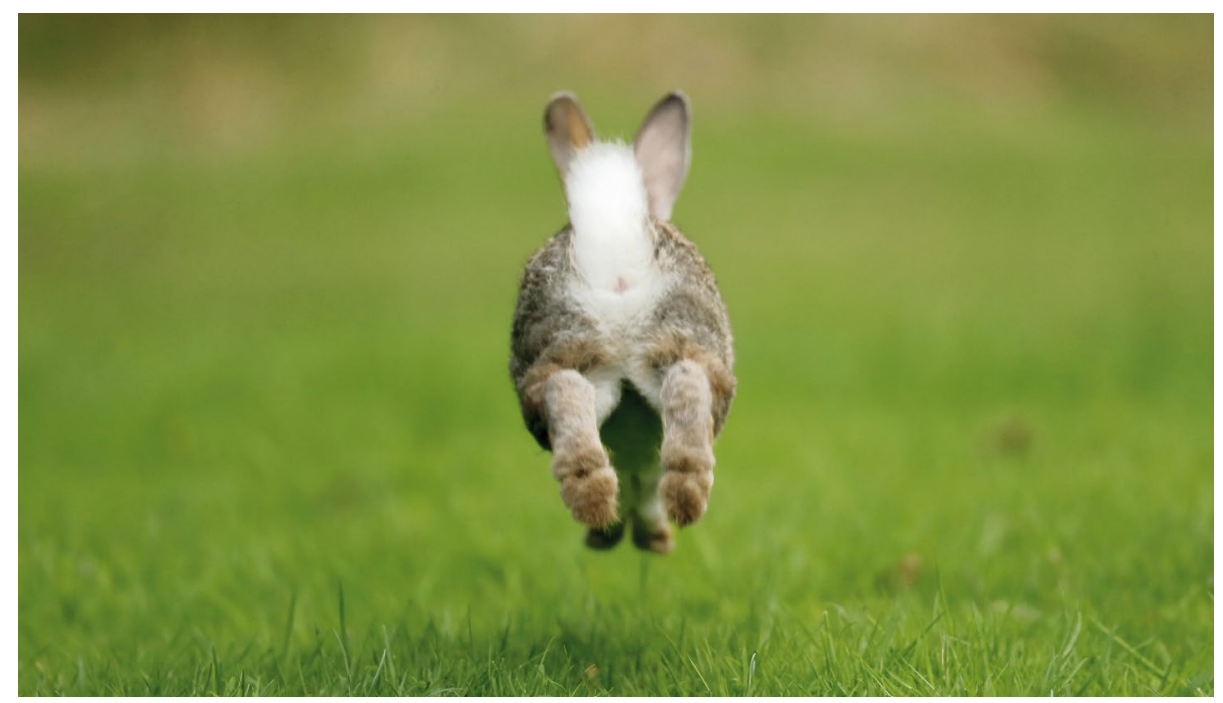

Antibody generation and production can happen without using animals and yield antibodies on par with traditional ones, a European Commission report says. Credit: FLPA / Alamy Stock Photo

dispel prejudices against recombinants, for which some companies are ramping up production. It's hard to predict how much change the change-makers can make, but change is afoot.

\section{Bye-bye, bunny}

Antibody catalogs mainly present animal-derived antibodies. That's something Alison Gray, an in vitro toxicologist and molecular biologist at the University of Nottingham who was part of the aforementioned EC report, would like to change. The most well-known research antibodies are polyclonals, which involve immunizing an animal, often a rabbit but sometimes a mouse, goat or other animal, to harvest antibodies from blood, says Fridtjof Lund-Johansen, a researcher at Oslo University Hospital. Catalogs present recombinant antibodies as well. These "sequence-defined" antibodies, says Bio-Rad's Achim Knappik, a biologist who has co-authored papers with Gray, can be made by cloning an antibody gene into an expression vector and then expressing that gene in a host cell line. Given their defined sequence, companies can alter these sequences to obtain modified recombinant antibodies, says
Lund-Johansen. Recombinant monoclonals can begin with immunization of mice or rabbits, followed by isolating and sequencing immunoglobulin $\mathrm{G}$ genes from $B$ cells and cloning them into an expression vector. Without animal immunization, one can use 'naive' libraries of immunoglobulin-encoding genes from donated human B cells, followed by different methods to select antibodies with specificities from this wide repertoire.

Monoclonal antibodies are traditionally made by injecting an antigen into an animal such as a mouse, or more recently a rabbit, says Lund-Johansen. B cells with specificity for the injected antigen are gathered from the animal's spleen; the cells are then fused to myeloma cells. This so-called hybridoma secretes antibodies specific to the injected antigen. With mouse monoclonals, the hybridoma can be cultured in vitro. But it has often been cultured by injecting it into a mouse's abdominal cavity where it grows in the ascites, secreting antibodies. The animal might start breathing rapidly, hunch over and decrease its activity, which can indicate pain ${ }^{6}$. Says Gray, “There's no scientific reason to carry on using the ascites method," which became popular due to its high yield. The EC report builds on a directive from 


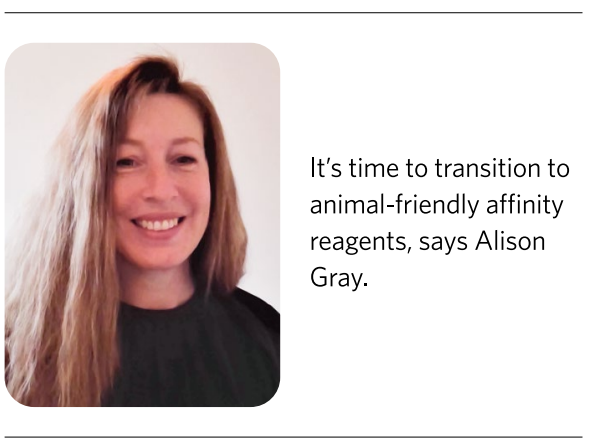

the European Union that prohibits the use of animals where alternative methods exist. In vitro methods work for making monoclonals. More generally, she says, antibodies on par with traditional ones can be made without animal use ${ }^{7,8}$.

In 2016, Gray founded the non-profit AFABILITY to advocate for animal-free antibody production and to advise on such methods. The EC report is now circulating through European Union member governments, who will decide individually on next steps. Similar activities are underway in the United States and Brazil, and at the Organisation for Economic Co-operation and Development. In the United Kingdom, irrespective of Brexit, AFABILITY will remain active. She and others believe animal-friendly affinity reagents make the use of animals obsolete.

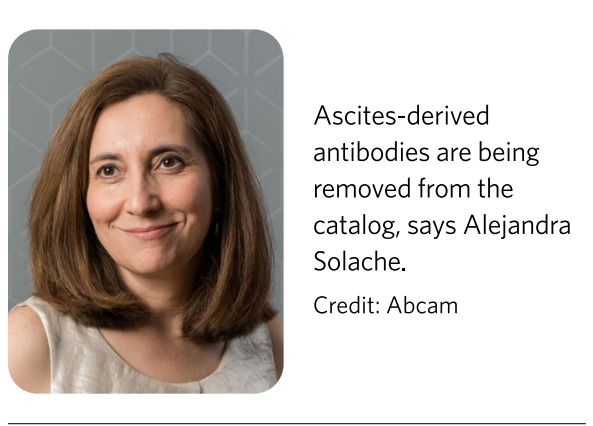

Polyclonals remain popular and customers like their low cost, says Alejandra Solache, Abcam's vice president of new product development. "But polyclonals vary from batch to batch, which means they need extensive and expensive characterization," she says. "I think polyclonals have had their time." She sees a bright future for recombinants. With the antibody-encoding genes on hand, a smaller version of a standard immunoglobulin G can be made or antibody fragments from rabbit can be converted to mouse. "That's something that we are also doing quite a bit," she says. Abcam has 20,000 recombinants in its catalog. Abcam does not produce monoclonals with the ascites method, says Solache. In the past, the company distributed ascites-derived antibodies. "But that's something we have now changed," she says, and ascites-derived antibodies are being removed from the catalog. Hybridomas can drift genetically or be contaminated, so Abcam is switching to recombinant monoclonals made in tissue culture. Antibody-producing genes are cloned into plasmids and expressed in mammalian cell lines.

If one wants to convert every new antibody to animal-free ones, "the technology is not quite there," she says. But it is "a big gain" to have reduced numbers of animals needed to make recombinant monoclonals and to use fewer animals than with polyclonals. Rabbit polyclonals can work for detecting post-translational modifications such as phosphorylation, but so can recombinant rabbit monoclonals, she says.

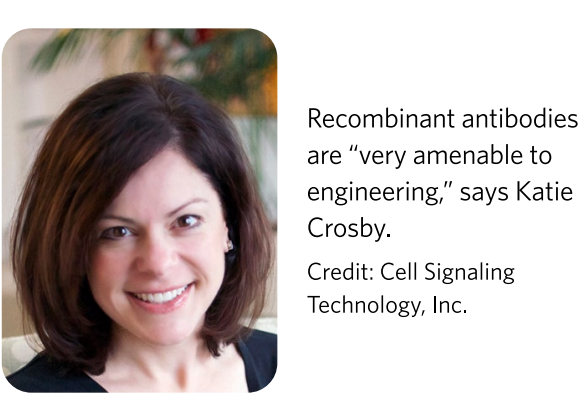

Cell Signaling Technology (CST) has used recombinant antibody production since 2007. The methods' advantage is that the antibodies are "very amenable to engineering," says Katie Crosby, who directs immunohistochemistry at CST. One might manipulate the heavy and light chain or use different backbone structures for the antibody. Hybridomas can be unstable and lose expression of the antibody or express additional light chains, which complicates antibody production. The CST process begins with animal immunization, followed by cloning into expression systems, says Crosby. The CST catalog contains no non-animal derived antibodies.

Given that the 'locked' recombinant sequences avoid genetic drift, says her CST colleague Joshua Nathan, recombinants can help labs focus on biological variability instead of variability due to an antibody's performance. Making recombinants is scalable, which helps labs doing long-term studies, says Crosby. Monoclonal antibodies are more consistent lot to lot than polyclonals and, in terms of consistency and scalability, "recombinant monoclonal antibodies are even better still.” At CST, ascites was used to manufacture antibodies, but it's "no longer the primary means," says Crosby. Animal-free antibody generation and production involve high-quality $\mathrm{cDNA}$ libraries and yeast or phage display. It takes skill, is costly, and involves multiple rounds of panning and eluting to find specific antibodies. "That is not something that every company is set up to do," she says.

The prospects for using non-animal sources when making antibodies "are pretty good," says Carl Ascoli, chief scientific officer of Rockland Immunochemicals. "I don't think we're there," so it's too soon to take tools out of the toolbox, he says. Polyclonals are ideal for many applications because they can attach to multiple epitopes. They take less technical skill than monoclonals or recombinants to make. Polyclonals are finite. Recombinants are specific and renewable, but cost more to produce. Over time, recombinant quality has improved, says Ascoli, and limitations ascribed to them are no longer quite true. "However, the range of targets against which these antibodies react is still limited compared to more conventional forms of antibodies, both polyclonal and conventional monoclonal," he says. He sees scientists mainly concerned with whether an antibody works. They seek evidence of specificity and sensitivity. "Whether the antibody is conventional or recombinant is a secondary concern to many researchers," he says. While there is increased production of recombinants, such as by cloning and direct nucleic acid synthesis, recombinant antibody technology has greater facility requirements and calls for more advanced skills for production compared to polyclonal and conventional monoclonal antibody development, he says.

When Knappik was at MorphoSys AG he developed a fully synthetic human combinatorial antibody library ${ }^{9}$. Bacteria are transformed with antibody genes, each clone containing a different antibody gene, and the antibodies are then 'displayed' on the surface of bacteriophages. Next steps include antibody selection and characterization. The antibodies are indistinguishable from any other antibody; they just have a different source, he says. "There is not at any point any animal involved in the design and construction process." Each antibody's defined sequence makes it possible to synthesize the antibody anew.

In her lab, Gray synthesizes the sequences of the antibodies she needs and applies the phage display method. "I don't touch humans or animals," she says. In her lab, those antibodies might be small ones based on published sequences of camelid antibodies or single-chain variable fragment 


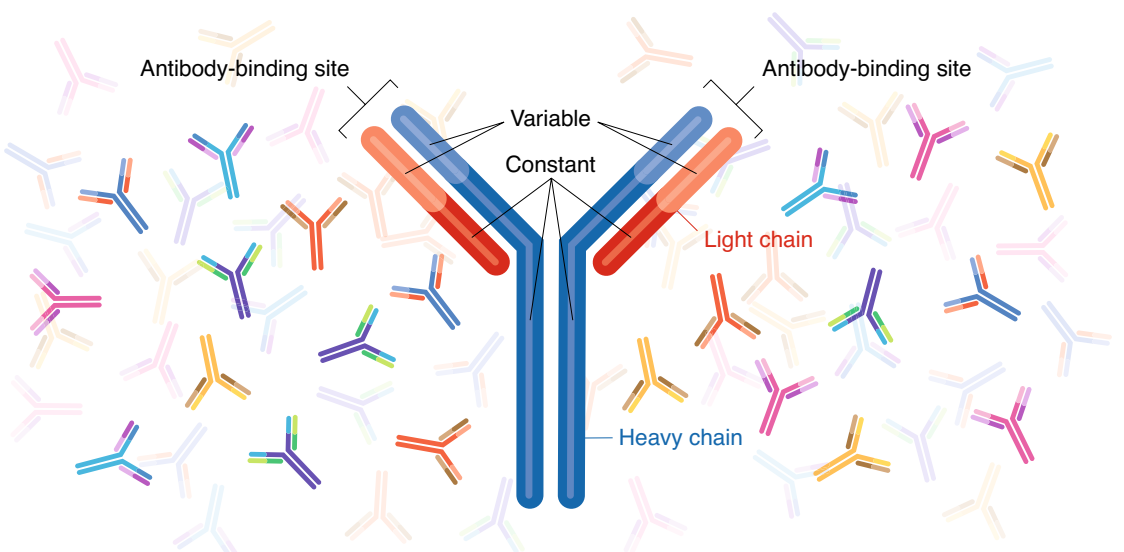

Animal-derived antibodies, such as those from mice and rabbits, and animal-free antibodies can have the same basic features. Of the estimated two to three million commercially available antibodies, recombinant antibodies make up a rapidly growing segment. Credit: Erin Dewalt, Springer Nature

$(\mathrm{ScFv})$ antibodies, a kind of recombinant with peptide-linked light and heavy chains.

Methods exist to make animal-free recombinant antibodies, and "the clever bit has been done already," says Gray, referring to display techniques to generate a library of genes. Making a library is not as easy as running a western blot, she says, but "it's standard molecular biology." She made her library in two months. Next is characterization, and there the sky is the limit in terms of time investment, she says. Companies transitioning to animal-free libraries will need to invest this time. But it lets them avoid licensing issues. Alternatively, they can buy animal-free libraries or the antibodies made from those.

Knappik was on the expert panel for the EC report about animal-free antibodies. The report does not bring overnight change, he says. European Union countries decide individually on practical measures that might follow. He thinks in vitro methods could be a viable replacement for traditional antibodies. "The mood is turning," he says, related to non-animal derived antibodies, which he has worked on for many years. The Bio-Rad catalog contains around 10,000 antibodies, animal-free ones among them. The MorphoSys method was proprietary and patented, and companies battled over patents, he says, given that these methods could ultimately make therapeutic antibodies, which need to not trigger an immune response. MorphoSys received regulatory approval for its antibody-based drug in 2017 and set up Antibodies by Design to develop non-animal recombinant antibodies for customers in research and diagnostics. Bio-Rad bought this company, and Knappik runs Bio-Rad's non-animal-derived antibodies division, which continues this service and makes
HuCAL antibodies for the catalog. The mention of HuCAL on the data-sheet indicates they are animal-free. As defined reagents, recombinants fit well into a climate of increased attention on reproducibility, says Knappik. In the future, he sees a large role for recombinant non-animal-derived antibodies, not just at Bio-Rad. These are renewable resources whereas animal-based antibodies are a "legacy product," he says. It saves no animals to stop selling existing antibodies; the animals used to generate those died long ago, says Knappik. Some companies continue to immunize animals and remain "in their own tradition," he says. Perhaps they are not following molecular cloning methods closely or the patent expiration of methods for making animal-free antibodies. "In principle every university could build their own library as a renewable source for antibodies in the future," says Knappik. "It's just a time thing; it will happen, the question is when."

\section{Fighting prejudice}

"There has been some prejudice," says Andrew Bradbury, a former Los Alamos National laboratory researcher, cofounder and chief scientific officer of Specifica, which develops non-animal-derived libraries and antibodies. He was also on the EC report's expert panel. Perception bias about recombinants, especially non-animal-derived ones, is a hangover from the early days of recombinants in the 1990s. Some labs had difficulty producing clones as single-chain variable fragments in bacteria. There were issues with the variable domains and with instability of the reagents. Some kits were made and sold before methods had matured. The early libraries were "rather small," says Knappik, with around one million to ten million antibodies. The resulting antibodies may have been low affinity; the larger the library, the greater the chance to find high-affinity antibodies. Also, some people overlook that antibodies from phage display libraries are monovalent. They have only one of the two arms of a typically Y-pronged antibody. Bacteria can't make bivalent ones, which, thanks to their two antigen-binding sites, can bind more strongly to antigens on, say, a cell surface. Some of his customers request monovalents, but typically he and his team convert monovalents into bivalents. Perhaps, he says, early library users applied monovalents. With a weakly expressed protein, those can fail on a western blot.

At Specifica, Bradbury generates and characterizes high-diversity libraries for recombinant antibodies. Each library is made with B cells from different human donors, he says. From a library particular targets of interest are selected and types of clones, clonotypes, are grouped computationally, such as according to how likely they are to bind to the same antigen. 'Binding loops' taken from sequenced human genes are placed in antibody scaffolds used in therapeutic antibodies known to be "well-behaved." Potentially problematic loops are eliminated before antibody selection. Bradbury sees many antibody companies slowly moving their production to recombinants, and also to non-animal-derived ones. It might not always be obvious that an antibody is animal free. An antibody company licensed one of his animal-free antibodies for detecting a post-translational modification. These are hard to detect because they are not as immunogenic. The company converted the antibody to look like a mouse monoclonal, he says.

Earlier this year, Bayer bought a Specifica library suite, which includes the library, protocols, vectors and training. Specifica also generates antibodies for a customer's designated targets. Naive libraries can deliver antibodies against anything, says Bradbury. "Now the libraries are really good and they can replace the use of animals," he says. Beyond making libraries, characterization is crucial and many assay types are needed including westerns, immunofluorescence,

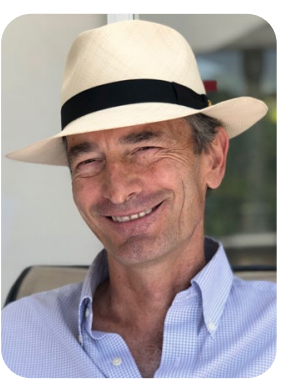

There has been some prejudice against non-animal-derived recombinant antibodies, says Andrew Bradbury. Credit: A. Bradbury-Aranda 
immunohistochemistry, flow cytometry, he says. "I think that's the biggest problem at the moment," he says. Traditional antibody manufacturers can make such libraries, but it's quite "a specialized art" to generate a functional one, says Bradbury. Twenty years ago, his first library had around 100 million different heavy-chain CDR3s (complementarity-determining region $3 \mathrm{~s}$ ), which are diverse binding loops. Much later, when they analyzed it with high-throughput sequencing, they learned the library had only three million unique CDR3s. The painful experience helped hone methods. To deliver high-affinity antibodies, libraries need to be big: these days his libraries have ten billion antibodies. Good selection strategies are essential. Phage display can be "a bit of a black box," says Bradbury. He combines yeast and phage display followed by high-throughput sequencing and machine learning to identify clonotypes. To advance animal-free antibody approaches and independent characterization will take funding. One assessment venture is at the Institute for Protein Innovation (IPI), set up by biotech entrepreneur Timothy Springer. The institute plans to characterize research antibodies and openly publish results. It seems a good idea, says Bradbury.

\section{A good, new world}

"I want to test 100,000 antibodies in my lab," says Lund-Johansen. He is tallying results from a recent series of blinded tests. He sent antibody companies a list of 3,000 proteins and asked them to send him 20 antibodies to some of these without disclosing which, and his lab determined the target experimentally. Results were mixed. Blinded tests matter because "you're so biased when you test an antibody in western blotting," he says. He would like to scale up this approach for very large numbers of antibodies and many assays. Given the size of the antibody market, large-scale characterization is a big task. "The most expensive part of putting an antibody in the catalog is not generation of the antibody, it's the characterization of the antibody," says Knappik. If immunization could be avoided "it would be wonderful," says Lund-Johansen. "Go vegan would be good.” Labs making antibodies from naive libraries "have to show and prove that they can make antibodies that are as good as the best ones that have been made by immunization," he says.

YCharOS, which has startup funding, is the brain child of Edwards and McPherson. The goal is a "public good," says Edwards, that aims to characterize all commercially available antibodies and place the information in the open domain. There are no patents

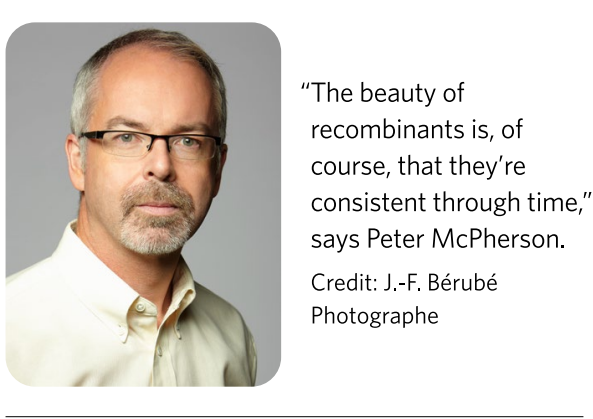

and no material transfer agreements. The umbrella organization is Agora Open Science Trust, a charity Edwards founded. "We don't have any skin in the game to care which antibody works or doesn't work," he says. "We do have skin in the game in helping fix science." The business model is like that of the food company Newman's Own, he says, in which all profits go to charity. Antibodies won't be ranked. The team will get antibodies from companies and perform blinded standard characterization experiments with knockout cell lines and then post the results openly. "The data will speak for themselves," he says. YCharOS is located in the McPherson lab, but the plan is to spin it out into an independent lab. "I think it's fantastic," says Gray about the large-scale characterization ventures. She hopes projects such as those at the IPI and YCharOS can be completed. Some antibodies will do better than others, says Edwards. YCharOS can show how well recombinant antibodies measure up to traditional ones. "Polyclonals, though, I do believe we should be getting rid of those," he says, given how variable lots can be. But traditions die hard. "Professors like us, we are so reluctant to change," he says. He wants high-quality reagents also for a pet project on less well-known proteins. "I'm agnostic as to how an antibody is made," he says. The experiments will reveal which work best. Gene-editing and knockout cell lines bring "quantitative biochemical thinking to antibodies," he says.

To expand antibody characterization, Abcam bought 3,000 cell lines and now has 5,000 of them. The company is checking whether antibody off-target binding might have been missed, says Solache. Using knockout cell lines - a gold-standard negative control - has led the company to remove antibodies from its catalog, "but we can only do as much as we can do by ourselves." Having others characterize antibodies is "absolutely the right thing to do," she says. Abcam will be providing reagents to YCharOS and is fine with the organization posting the results openly. The project can help the company identify antibodies not performing well, and "the more people that can do that, the merrier," she says. "We want them to succeed." Academic credibility, good standard operating procedures, open data, impartiality and charity ownership are crucial for YCharOS, says McPherson. YCharOS might be where Laflamme, his postdoc, continues his career. Edwards and McPherson will likely join the scientific advisory board but McPherson will stay at McGill. "I love doing neuroscience," he says. YCharOS will help him make antibody choices for his amyotrophic lateral sclerosis and frontotemporal dementia research, guide other labs as well, and keep "garbage" out of the scientific literature, he says. Even with data from YCharOS, labs should still do additional antibody characterization for their applications, he says. He also knows researchers confess to skipping these tasks. "It's a cultural issue, it's not a scientific issue," says McPherson, but YCharOS could help change that culture.

In most labs, says Gray, antibodies are not a research focus but rather a tool for exploring hypotheses. Researchers check for bands in a western, stare at their flow cytometers and watch for fluorescence under the microscope. "They just want to show that the proteins that they want to show are there," she says. As for antibodies "they just want to buy it, use it, forget about it." This culture makes it tough to discuss the animal origin of research antibodies. Despite the "uphill climb," she won't stop striving for change. The antibody world is changing. Recombinants are gaining traction. Perhaps offerings will grow more diverse and perhaps non-animal-derived recombinants will win the day. Methods advances enable new types of antibodies and characterization. "We're trying to create a better world," says Edwards.

Vivien Marx ${ }^{\bowtie}$
Nature Methods.
$\aleph_{\text {e-mail:v.marx@us.nature.com }}$

Published online: 22 July 2020

https://doi.org/10.1038/s41592-020-0915-8

References

1. Taussig, M. J. et al. Nat. Methods 4, 13-17 (2007).

2. Colwill, K. Renewable Protein Binder Working Group \& Gräslund, S. Nat. Methods 8, 551-558 (2011).

3. Bradbury, A. \& Plückthun, A. Nature 518, 27-29 (2015).

4. Uhlen, M. et al. Nat. Methods 13, 823-827 (2016).

5. Barroso, J., Halder, M. \& Whelan, M. EURL ECVAM recommendation on non-animal-derived antibodies (Publications Office of the European Union, 2020); https://doi. org/10.2760/091625

6. National Research Council (US) Committee on Methods of Producing Monoclonal Antibodies. Monoclonal Antibody Production Ch. 6. Animal-welfare issues related to the ascites method for producing monoclonal antibodies. (National Academies Press, 1999).

7. Gray, A. C. et al. Nature 581, 262 (2020).

8. Gray, A. C. et al. Nat. Methods https://doi.org/10.1038/s41592020-0906-9 (2020).

9. Knappik, A. et al. J. Mol. Biol. 296, 57-86 (2000). 